\title{
Jan Kofman
}

\section{Totalitaryzm a PRL \\ DOI: $10.35757 /$ CIV.2012.14.03}

Można rozpocząć od oczywistego stwierdzenia, że Polska 1951 roku była inna niż Polska lat 1956-1967, podobnie jak schyłkowa faza epoki Władysława Gomułki różniła się od początku rządów Edwarda Gierka, a kraj lat 1980-1981 rażąco odbiegał od okresu między 13 grudnia 1981 roku a 1986 rokiem, inna również była rzeczywistość okresu od jesieni 1986 do początku 1988 roku czy wreszcie samego końca Polski Ludowej - od wiosny 1988 roku do pierwszych miesięcy 1989 roku. W wymiarze podjętego tematu ważniejsze niż wskazanie odmienności okresów w historii PRL wydaje się jednak pytanie o to, co ustrojowo było rzeczywiście wspólne dla tak różnych okresów Polski Ludowej.

Zauważmy choćby to, że chętnie do dziś oglądane peerelowskie produkcje telewizyjne - rozpatrywane $z$ punktu widzenia oceny świadomości historycznej społeczeństwa - mówią coś istotnego o charakterze pamięci o komunizmie. Co interesujące, wciąż silnej w społeczeństwie i zastanawiająco wolno wygasającej afirmacji tej przeszłości niejednokrotnie towarzyszy bezrefleksyjne przekonanie o bezgrzesznym narodzie, trwajaccym bowiem w oporze przeciwko systemowi. Oba te zjawiska, niespójne wewnętrznie, znajdujące się skądinąd w swoistej mentalnej wzajemnej opozycji, były - i do pewnego stopnia sa nadal - podzielane przez nierzadko te same osoby, środowiska oraz grupy społeczne, znajdując potwierdzenie w badaniach opinii publicznej.

Jan Kofman - profesor, historyk i politolog, pracownik Instytutu Historii i Nauk Politycznych Uniwersytetu w Białymstoku. 
Spróbujmy się z kolei zastanowić nad systemową istotnością Polski Ludowej. Czy była ona państwem totalitarnym, posttotalitarnym, czy (aż) tylko autorytarnym lub, jak sązą niektórzy - po październiku 1956 roku - umiarkowanej, bezprzymiotnikowej jedynie dyktatury? A może jej cechy pasowały bardziej do innych jeszcze ujęć teoretycznych, bliższych podejściu zrywającemu z klasycznym modelem totalitaryzmu, podobno całkowicie nieadekwatnym do przedstawienia przed- czy poststalinowskiego komunizmu w Związku Radzieckim i niemal wszędzie w Europie Środkowo-Wschodniej? Zbliżone np. do koncepcji Juana José Linza i Alfreda Stepana (obok totalitaryzmu wyróżniającej trzy typy posttotalitaryzmu i - za Kennethem Jowittem - sułtanizm), poglądów tzw. drugiego pokolenia rewizjonistów wśród specjalistów amerykańskich czy, powiedzmy, do ujęcia uznającego ten pierwotny paradygmat (totalitaryzm) za równorzędny $z$ innymi badawczymi kierunkami (modernizacyjnym, grupowym, porównawczym, kulturowym) albo - w odniesieniu do sytuacji po 1956 roku - zastępującego go oryginalna koncepcją korporatywizmu Philippe'a Schmittera (uznająca komunizm za swoisty system reprezentacji interesów).

Polska refleksja socjologiczno-politologiczna i historyczna na temat istoty rodzimej wersji komunizmu (np. Andrzej Antoszewski, Marek Bańkowicz, Ryszard Herbut, Winicjusz Narojek, Andrzej Rychard, Jadwiga Staniszkis, Hanna Świda-Ziemba, Andrzej Walicki, Edmund Wnuk-Lipiński, Wojciech Sokół, Marek Żmigrodzki, Tomasz Żyro, inni badacze ze szkół wrocławskiej, lubelskiej i - w pewnym stopniu - krakowskiej czy historycy, jak Błażej Brzostek, Antoni Dudek, Jerzy Holzer, Jerzy Eisler, Andrzej Friszke, Dariusz Jarosz, Krystyna Kersten, Paweł Kowal, Marcin Kula, Paweł Machcewicz, Andrzej Paczkowski, Wojciech Roszkowski, Dariusz Stola, Marcin Zaremba) nawiazuje $z$ reguły albo do jego wspomnianego klasycznego modelu (czyli zadłużonego u Hannah Arendt), albo do koncepcji wyżej zasygnalizowanych, rzadziej proponując samodzielne interpretacje. 
Względnie popularny wśród polskich specjalistów jest pogląd, że - wyjąwszy okres stalinizmu - Polska Ludowa była co najwyżej krajem autorytarnym, i to właściwie w „miękkiej” wersji autorytaryzmu. Przyjmowaniu takiej interpretacji sprzyjaja - obecne m.in. w obiegu politologicznym - konstrukty myślowe pokrewne odnotowanemu już głośnemu stanowisku Juana J. Linza i Alfreda Stepana. Na przykład jedna $z$ systematyk powołuje do życia autorytaryzm socjalistyczny, majacy cechować Europę Środkowo-Wschodnia od połowy lat 50. XX wieku, w jego ramach wydzielając jeszcze kolejne podsystemy (jak quasi-konsultacyjno-autorytarny w Czechosłowacji przed 1968 rokiem, konsultacyjno-autorytarny, m.in. w Niemieckiej Republice Demokratycznej, czy pluralistyczno-autorytarny $-\mathrm{z}$ Polska w latach 80 . XX wieku). Z kolei historycy postrzegaja PRL po 1956 roku raczej jako system autorytarny, ale bez tego socjalistycznego kwalifikatora (np. Marcin Kula czy Dariusz Stola), lub akcentuja "twarda” jego wersję - Polska Ludowa jako byt „autorytarny $z$ wyraźnymi tendencjami totalitarnymi" (Jerzy Eisler, podobnie m.in. Antoni Dudek).

Czy zatem Polska Ludowa była niepełnym autorytaryzmem, pewna wersja korporatywizmu, dyktatura nowej generacji, mieszanką lub wypadkową w różnej proporcji tych klasyfikacji, a może jednak systemem totalitarnym? Wybór odpowiedzi - definiowany treścia pamięci o wspólnej przeszłości, do jakiej się odwołujemy - określa nasz stosunek do kwestii jej oceny i rozliczenia, w konsekwencji zaś stawia problem osobistego $z$ nia rozrachunku.

Według głośnej interpretacji Andrzeja Walickiego, w zestawieniu ze stalinizmem jako apogeum komunistycznego totalitaryzmu, Polska Ludowa od jesieni 1956 roku była oczywistym postępem. Niekiedy logika takiego założenia mogła w konsekwencji prowadzić m.in. do dość nieoczekiwanej konkluzji o charakterze czysto politycznym (i rzeczywiście prowadziła, nie tylko zreszta Walickiego), że po 13 grudnia 1981 roku o dalszej ewolucji systemu w ramach PRL mógł przesądzić jakiś rodzaj modus vivendi $z$ reżimem, choć $z$ wykluczeniem Solidarności. Trudno, rzecz jasna, polemizować 
$z$ takim sądem, tyle że $z$ kolei $-z$ perspektywy heroicznej wersji polskich dziejów - Polska Ludowa będzie niemal tak samo godna potępienia po 1956 roku, jak i przed nim.

Wiele lat temu (w 1991 lub 1992 roku) uczestniczyłem w dyskusji zorganizowanej w Instytucie Studiów Politycznych Polskiej Akademii Nauk, w której Krystyna Kersten interesująco rozważała argumenty za pociagajaca niektórych badaczy - przypomniana przez Antoniego Dudka w 2008 roku - hipoteza (sama nie będąc do niej przekonana), że państwo satelickie ze swojej istoty może być nie tyle państwem totalitarnym, ile bardziej już kolonią. Broniłem wówczas (i czynię to nadal) poglądu, że Polska Ludowa była jednak krajem totalitaryzmu. I to nie tylko w szczytowym okresie stalinizmu (co interesujace, w wypadku Polski uznawanego przez Linza i Stepana za... fazę autorytaryzmu), datowanego przez większość badaczy na lata 1949-1955, a który, według nie tylko mojego przekonania, trwał już od chwili zainstalowania w kraju Polskiego Komitetu Wyzwolenia Narodowego. To, że Polska Ludowa nie była suwerenna, będąc być może - co jest, powtórzę, wątpliwe - także radziecką kolonią (jeśli już, to najwyżej quasi-kolonia), nie wyklucza, że w wyniku tej relacji była totalitarna.

Istnieje oczywisty bezpośredni i genetyczny związek między cechami funkcjonującego przez blisko pół wieku ustroju a oddziaływaniem sąsiedniego czynnika zewnętrznego. Polska stała się totalitarna w decydujacym stopniu pod naciskiem i kuratela Zwiazku Radzieckiego. Była to jednak nie zwyczajna forma nacisku, jaki niejednokrotnie przecież występuje $\mathrm{w}$ relacjach międzynarodowych, ale narzucona wszechstronna i głęboka podległość ideologiczna, polityczna, gospodarcza, wpływajaca istotnie na sytuację wewnętrzna i opresyjność systemu w latach 1945-1988/1989.

Zewnętrzna suwerenność Polski Ludowej i jej przywódców była właściwie żadna. Wbrew podtrzymywanym (nierzadko jeszcze i dziś) opiniom, stwierdzenie to dotyczy również takich przedsięwzięć, jak plan Rapackiego z 1957 roku o utworzeniu strefy bezatomowej w Europie Środkowej, traktat podpisany przez Polskę i Republikę 
Federalna Niemiec w 1970 roku czy wprowadzenie przez generałów stanu wojennego. Te i podobne wydarzenia nie były skutkiem samodzielnej aktywności, ale zawsze stanowiły wynik uzgodnień $z$ Kremlem lub realizacje jego dyrektyw.

Niewatpliwie Moskwa również decydowała lub - rzadziej - co najmniej współdecydowała o kierunku i znaku polskich przesileń wewnętrznych czy o zmianach na szczytach Polskiej Zjednoczonej Partii Robotniczej. Tak było w 1948 roku, w październiku 1956 roku, w grudniu 1970 roku, w sierpniu 1980 roku, w październiku i grudniu 1981 roku czy w latach 1988-1989. Niemniej jednak w latach oddzielanych tymi „polskimi miesiacami” władze PRL dysponowały pewnym zakresem - mniejszej lub większej - suwerenności wewnętrznej (wyjąwszy oczywiście apogeum stalinizmu).

Ideowa podstawa totalitaryzmu komunistycznego było, jak wiadomo, dążenie do zbudowania idealnego społeczeństwa. Do konstytutywnych cech systemu - zgodnie $z$ klasyfikacja totalitaryzmu wyłożona jeszcze przez Carla Joachima Friedricha i Zbigniewa Brzezińskiego (później nieco zmodyfikowaną przez pierwszego $z$ nich) - należała władza masowej monopartii, złączonej licznymi więzami $z$ biurokracja państwową i gospodarczą. Monopartia przez dziesięciolecia sprawowała rządy, w pełni kontrolując (m.in. przez system nomenklatury, który objał z czasem około 300 tys. najważniejszych stanowisk) życie polityczne, gospodarcze, społeczne i kulturalne. Podstawowym narzędziem panowania partii komunistycznej był podporzadkowany jej aparat przemocy - od sił zbrojnych, przez służby specjalne, w tym policję polityczną (liczaca w końcu lat 80. XX wieku 100 tys. różnej kategorii współpracowników), po rozbudowane formacje pomocnicze (np. Ochotnicza Rezerwa Milicji Obywatelskiej), ale także bardzo silna penalizacja wymiaru sprawiedliwości.

Niewatpliwa cecha PRL były ponadto represje stosowane wobec przejawów oporu społecznego, przyjmujące okresowo nawet formę terroru państwowego. W dziesięcioleciu powojennym terror ten był kierowany najpierw masowo, później powszechnie (według 
podziału zaproponowanego przez Andrzeja Paczkowskiego) przeciw podziemiu zbrojnemu i politycznemu oraz różnym grupom i środowiskom społecznym. Po 1956 roku represji używano okresowo wobec wybranych grup ludności i opozycji politycznej, a po 13 grudnia 1981 roku - również przeciw Solidarności. Także partia przechodziła w różnych okresach czystki, które miały na celu zastraszenie zarówno jej członków, jak i - pośrednio - ogółu społeczeństwa.

Propaganda (w jej ramach zaś okazjonalne kampanie nienawiści, np. przeciw kułakom, tzw. prywaciarzom, duchowieństwu katolickiemu, „sługusom imperializmu”, „syjonistom”, „wichrzycielom”, solidarnościowej „ekstremie”) prowadzona przez niemal $\mathrm{w}$ pełni kontrolowane przez partię media to inny ważny instrument jej panowania, służący mobilizacji i zarazem zastraszaniu (niekiedy wręcz terroryzowaniu) ludności. Podobny cel osiagano także przez akcje masowe (wiece, manifestacje, przemarsze), będące skutecznym mechanizmem kształtowania ukierunkowanej przez partię aktywności politycznej społeczeństwa i jego konsolidacji (np. w pierwszej połowie lat 50. XX wieku, w 1968 roku, w czerwcu 1976 roku, również później obejmującej całkiem spore jego odłamy).

Polskę Ludowa charakteryzowały omnipotencja państwa, skrajne zetatyzowanie wszystkich dziedzin życia, ograniczenie praw własności, zdecydowana przewaga własności państwowej nad jej innymi formami, a w gospodarce - centralne planowanie i (bardzo długo) system nakazowo-rozdzielczy.

Totalitaryzm w skrajnej formie nie występował w PRL, wyjąwszy początek lat 50. XX wieku, gdy był tego bliski. Późniejsze kolejne kryzysy społeczne (rewolty i wystapienia pokojowe) wprawdzie osłabiały system i skutkowały jego zmianami, ale - wbrew optymistycznej wykładni tych wydarzeń (np. według Andrzeja Walickiego czy, w pewniej mierze, Jerzego Eislera) - był to proces dalece niejednoznaczny pod względem kierunku, okresy liberalizacji przeplatały się bowiem ze zwrotami o charakterze regresywnym. 
Podczas gdy w dekadzie popaździernikowej więzienie za poglądy i przekonania zdarzało się - właśnie w wyniku wydarzeń 1956 roku - rzadko, to w marcu 1968 roku stosowano już szerokie represje wobec młodzieży, a także według klucza narodowościowego. W grudniu 1970 roku strzelano do ludzi i zabijano ich, w czerwcu 1976 roku stosowano „ścieżki zdrowia” i organizowano masowe wiece poparcia dla władzy, w grudniu 1981 roku zabito górników w kopalni "Wujek” oraz internowano i uwięziono około 10 tys. osób, tysiące pozbawiono również zatrudnienia, $z$ kolei przez lata 80. XX wieku bezwzględnie i na wielka skalę zwalczano podziemie opozycyjne i solidarnościowe. Nierzadko więc system - po wstrząsie czy wybuchu społecznym - był przez pewien okres bardziej represyjny niż w dziesięcioleciu po 1956 roku i pierwszych latach rządów Edwarda Gierka, partia zaś usiłowała przywrócić możliwie ściśle poprzedni zakres oraz dawną treść swojego władztwa.

Chyba najpełniej i najbardziej wnikliwie uzasadniali prawomocność definiowania reżimu PRL jako autorytarnego przywoływani już Juan J. Linz i Alfred Stepan. Stanowisko to budzi jednak wątpliwość, jeśli przypomnimy, że np. jedna $z$ podstawowych jego cech jest oparcie się na autorytecie jednostki lub grupy (do czego obaj badacze właściwie nie nawiąują). A przecież w PRL koincydencja ta $\mathrm{w}$ istocie nie występowała. Wyjąwszy wydarzenia przełomowe (np. rok 1956 czy, w mniejszym stopniu, początek rządów Gierka), kiedy społeczna akceptacja dla pierwszego sekretarza Komitetu Centralnego PZPR (nietożsama $z$ aprobata dla partii) była szeroka, przywódców komunistycznych popierały zwłaszcza (choć przecież nie jedynie!) grupy zainteresowane trwaniem systemu - funkcjonariusze aparatu bezpieczeństwa, armii, wymiaru sprawiedliwości, wyższej administracji państwowej, nomenklatury, a także członkowie ich rodzin. Czyli jednak kilka milionów osób! Czy dla rządów partii wsparcie to było skutkiem autorytetu jej szefa? Wattpliwe, jeśli przywołać łatwość, $z$ jaka społeczne zaplecze systemu przyjmowało zmiany na szczytach władzy. 
Zarazem niejednokrotnie można spotkać opinię, formułowana jako bezdyskusyjny pewnik, że wobec komunizmu społeczeństwo trwało $\mathrm{w}$ konsekwentnym oporze, przynajmniej biernym. Już w świetle tego, co przed chwila zostało podniesione, stwierdzenie takie nie jest niczym więcej niż ideologicznym uproszczeniem czy po prostu pseudopatriotycznym frazesem. W istocie bowiem zmienne poparcie dla systemu bywało nierzadko jeszcze bardziej rozległe niż tylko ze strony wyżej wspomnianych środowisk związanych $z$ aparatem władzy. Było zarówno aktywne, jak i przecież bierne (jak szerokie?), wynikające m.in. $z$ konformizmu indywidualnego i społecznego. Oprócz heglowsko „ukąszonej” (raczej na krótko) inteligencji projekt nowej rzeczywistości pociagał wielu robotników, chłopów, ludzi młodych, wiażąc ich $z$ władzą i partią. Ponadto stosunkowo trwałe więzi naprawdę dużych i różnych grup społeczeństwa $z$ władza miały racjonalne (w tym materialne i psychologiczno-świadomościowe) podstawy, były przecież skutkiem awansu społecznego setek tysięcy czy milionów osób. To oni - dzieci chłopskie i robotnicze oraz ich dzieci - byli, przynajmniej okresowo, beneficjentami Polski Ludowej.

Warto jeszcze zauważyć, że rozmiar społecznego zaplecza władzy był każdorazowo wskaźnikiem stopnia jej legitymizacji, która tę zależność dobrze rozumiała. Podczas gdy np. dla Władysława Gomułki oczywistą (następująca przecież po nocy stalinizmu) formą relegitymizacji rządów PZPR - czyli właśnie dążenia do poszerzenia społecznego poparcia wykraczajacego poza udzielane jedynie przez "systemowy” elektorat - była tzw. mała stabilizacja, to dla Wojciecha Jaruzelskiego po 13 grudnia 1981 roku sytuacja była znacznie gorsza. O ile bowiem Gomułka, obejmując władzę jako pierwszy sekretarz partii, otwierał przed ludźmi nadzieję zmian, o tyle Jaruzelski przeciwnie: dla większości z nich oznaczał jej utratę i traumę stanu wojennego. I choć w drugiej połowie lat 60. XX wieku Gomułka i PZPR tracili legitymację do sprawowania władzy (zdaniem Hanny Świdy-Ziemby wręcz zmierzali do odbudowy twardego totalitaryzmu), to Jaruzelski w istocie jej społecznej 
autoryzacji nie uzyskał. I nic dziwnego! Gdy zatem - powtórzę - dojście Gomułki do władzy przyniosło swoista, choć przejściowa liberalizację reżimu, to rządy Jaruzelskiego (przez kilka lat jednocześnie pierwszego sekretarza Komitetu Centralnego, premiera, ministra obrony narodowej, przewodniczacego Wojskowej Rady Ocalenia Narodowego) totalitarny charakter systemu właściwie jednoznacznie na pewien czas przywróciły.

Kiedy zatem - wracając do głównego toku rozważań - z czasem ideologia oficjalna okazywała się coraz bardziej oczywistym, pełnym obłudy i uwierającym wielu ludzi rytuałem (historycy różnie datuja ten moment: jedni wskazuja już okres wspomnianej małej stabilizacji, inni - lata 1968-1970, jeszcze inni - połowę dekady władzy ekipy Gierka czy - takich ocen również jest sporo - dopiero lata 1980-1981), ich stosunek do partii i ustroju ewoluował, przynajmniej w dwóch kierunkach: odrzucenia czy buntu albo konformizmu.

Nie można również pomijać znaczenia faktu, że większość społeczeństwa, dostosowujac się do systemu, poszukiwała swoistego kontraktu $z$ władzą. Przez dziesięciolecia życia w PRL ludzie nabrali nawyku zachowań, które przyjęło się określać (za m.in. Krystyna Kerstenową i Andrzejem Friszkem) jako przystosowanie i opór. Przystosowaniem było wchodzenie w system, płytsze lub głębsze zakorzenianie się w nim, aż po jego akceptację; opór także był stopniowalny - od biernego w różnych formach po czynny (np. od właczania się $\mathrm{w}$ struktury opozycyjne po opór zbrojny w pierwszych latach po wojnie). Pragnienie przystosowania się do nowych okoliczności było skądinąd naturalne i tym łatwiejsze, że po 1956 roku władza „dawała ludziom żyć” oraz do pewnego stopnia pozwalała Polakom realizować ambicje zawodowe czy społeczne. Pod warunkiem nieokazywania przez nich sprzeciwu (nawet jedynie werbalnego) wobec zasad ustrojowych, wprowadzonych rozwiąań instytucjonalnych oraz oczekiwań, żądań i nacisków ze strony PZPR (choćby na rzecz masowego uczestnictwa w wyborach czy biernego akceptowania socjalistycznej ojczyzny i stojącej za nią ideologii). 
Z kolei aktywne i szerokie przejawy czynnego oporu, nieoczekiwane narodowe i społeczne uniesienia nie moga trwać wiecznie. Szesnaście miesięcy Solidarności trzeba uznać za wyjątkowo długi okres takiej euforii. Choć przecież i wtedy większość ludzi opowiadała się za socjalizmem - może bardziej sprawiedliwym, „naszym”, z ograniczoną władzą partii i z obecnością Solidarności. A jednak po 13 grudnia 1981 roku setki tysięcy członków zawieszonej Solidarności weszły jednak, $z$ różnych powodów, do związków branżowych i Ogólnopolskiego Porozumienia Związków Zawodowych tworzonego przez władze. Co więcej, jeszcze wiele lat po upadku komunizmu wprowadzenie stanu wojennego uzyskiwało wysoki poziom społecznej akceptacji. Nie wiemy dokładnie, jak liczni byli ci, którzy w różnych okresach istnienia PRL mieli poczucie, że żyja w kraju niedemokratycznym i dyktatorskim. Nie wydaje się również, aby Polaków umiłowanie demokracji było wtedy tak powszechne, jak lubimy sądzić. Trudno inaczej wyjaśnić (i zrozumieć), dlaczego $\mathrm{w}$ przełomowych wyborach czerwcowych w 1989 roku uczestniczyło jedynie 62\% uprawnionych, podczas gdy za rządów Gomułki, Gierka i Jaruzelskiego brało w nich udział 95-98\% (jedynie w 1985 roku 79\%), głosując właściwie tak, jak tego oczekiwała partia. Niewatpliwie te $i$ inne fakty utrudniaja jeszcze rzeczywiste rozliczenie się $z$ Polska Ludowa. Tym bardziej że różne warstwy społeczne i środowiska, jeśli nawet okresowo nie akceptowały systemu lub przyjmowały go wstrzemięźliwie, bardzo długo (do kiedy: sierpnia 1980 roku, 13 grudnia 1981 roku czy czerwca 1989 roku?) uważały PRL za swoje państwo. Przyczyny tej postawy były skomplikowane i sa różnie interpretowane. Niewykluczone, że jednym $z$ jej źródeł było np. dość powszechne zrównywanie treściowe pojęć ojczyzny i państwa oraz wynikająca $z$ niego emocjonalna i (lub) rozumowa akceptacja rzeczywistości.

Polskę Ludową można przedstawiać za pomoca różnych narracji - tworzonych przez ludzi o odmiennych życiorysach i przez to rozmaicie pamiętających ten czas. Dla jednych to pamięć własnej młodości, w związku $z$ tym - nawet tęsknoty za czasem minio- 
nym. Dla innych to wspomnienie terroru, przemocy, panowania kłamstwa. Bywa i tak, że dla stosunkowo wielu PRL jest i jednym, i drugim. Wyjąwszy lata stalinizmu, było to państwo „liberalniejsze" i bez wattpienia normalniejsze niż o wiele bardziej totalny Związek Radziecki czy np. zachodnia rubież obozu - Niemiecka Republika Demokratyczna. Jest oczywiste, że dzieje PRL wymagaja rzetelnej i obiektywnej refleksji, a także zrozumienia, że cokolwiek powiemy, dzisiejsza Polska również z niej wyrasta.

Konkludując, podzielam pogląd - zapewne mniejszości badaczy - że choć granice między autorytaryzmem a niepełnym (ułomnym) totalitaryzmem sa nieostre, wiele wskazuje jednak na to, że mniej więcej do lat 1988-1989 nadal funkcjonował w Polsce system odznaczajacy się zdecydowana przewaga zawartych w nim elementów totalitaryzmu (także w sferach ustrojowej i prawnej), po które partia komunistyczna sięgała w sytuacjach, gdy uznawała je za niezbędne dla utrzymania swojego panowania. 